\title{
Skrining Aktivitas Antibakteri Ekstrak Etanol 70\% Sepuluh Daun Tanaman Terhadap Klebsiella Pneumoniae
}

\section{Antibacterial Activity Screening of Ten Leaves Extracts against Klebsiella Pneumoniae}

\author{
Nurul Qolbi* dan Ratna Yuliani \\ Fakultas Farmasi, Universitas Muhammadiyah Surakarta, Jl. A. Yani Tromol Pos 1 Surakarta 57162 \\ *email: nurulmadinahtulqolbi@gmail.com
}

\begin{abstract}
Abstrak
Klebsiella pneumoniae adalah bakteri penyebab penyakit infeksi seperti penyakit paru obstruksi kronik dan pneumonia. Antibiotik yang digunakan untuk menangani penyakit infeksi tersebut menyebabkan efek samping sehingga perlu adanya alternatif obat dari bahan alam yang dapat menghambat K. pneumoniae. Penelitian ini bertujuan untuk mengetahui aktivitas antibakteri ekstrak etanol $70 \%$ sepuluh daun tanaman terhadap $K$. pneumoniae, mengetahui golongan senyawa, dan golongan senyawa aktif antibakteri dalam ekstrak daun tanaman yang memiliki diameter zona hambat terbesar. Ekstraksi senyawa dalam daun dilakukan menggunakan penyari etanol $70 \%$ dengan metode maserasi. Uji aktivitas antibakteri dilakukan menggunakan metode difusi disk. Identifikasi golongan senyawa yang terkandung dalam ekstrak yang memiliki diameter zona hambat terbesar dilakukan menggunakan Kromatografi Lapis Tipis (KLT). Bioautografi dilakukan untuk mengetahui golongan senyawa aktif dalam ekstrak yang memiliki aktivitas antibakteri tertinggi. Hasil skrining aktivitas antibakteri menunjukkan bahwa semua ekstrak mempunyai aktivitas antibakteri kecuali ekstrak daun bambu. Ekstrak etanol daun sukun (Artocarpus altilis)mempunyai aktivitas antibakteri tertinggi dengan diameter zona hambat sebesar 18,33 \pm 5,57 mm. Kandungan senyawa dalam daun sukun adalah tanin, polifenol, alkaloid, terpenoid, dan saponin sedangkan golongan senyawa yang diduga memiliki aktivitas antibakteri adalah terpenoid dan saponin.

Kata kunci: antibakteri, Klebsiella pneumoniae, Artocarpus altilis, bioautografi.
\end{abstract}

\begin{abstract}
Klebsiella pneumoniae causes several diseases such as chronic obstructive lung disease and community pneumonia. The antibiotics used for treating the infectious diseases cause several side effects. Therefore, alternative medicines which have minimal side effects are needed. This research aimed to investigate antibacterial activity of ten ethanolic extract of leaves against $K$. pneumoniae, identify compounds and active compounds in extract which has the highest antibacterial activity. Compounds in leaves were extracted using 70\% ethanol with maceration method. The disk diffusion method was used for screening antibacterial activity against K. pneumoniae. The identification of group of compounds in extract with the largest inhibitory zone diameter was done using Thin Layer Chromatography (TLC) and bioautographic test was performed to determine the active compounds. The results of antibacterial activity screening tests showed that all extracts have antibacterial activity except bamboo leaf extract. Breadfruit extract (Artocarpus altilis) has the highest antibacterial activity with diameter of inhibition zone of 18,33 $\pm 5,57 \mathrm{~mm}$. Breadfruit extract contains tannin, polyphenol, alkaloid, terpenoid, saponin, and the active antibacterial compounds were terpenoid and saponin.
\end{abstract}

Keywords: antibacteria, Klebsiella pneumoniae, Artocarpus altilis, bioautography.

\section{PENDAHULUAN}

Klebsiella pneumoniae adalah bakteri Gram-negatif, non-motil, tidak berkapsul, memfermentasi laktosa, bersifat anaerob fakultatif yang merupakan kelompok Enterobakteriaceae (Elmer et al., 2006). K. pneumoniae merupakan salah satu bakteri penyebab infeksi nokosomial seperti penyakit paru obstruksi kronik (PPOK), pneumonia, dan infeksi saluran kemih (ISK). Hal ini disebabkan karena Klebsiella pneumoniae memiliki kemampuan untuk menyebar dengan cepat. $K$. pneumoniae berada dalam saluran pernafasan dan tinja kurang lebih 
pada 5\% individu normal akan tetapi penyebaran utama Klebsiella pneumoniae adalah di saluran pencernaan. Infeksi terbanyak yang disebabkan oleh $K$. pneumoniae adalah infeksi saluran kemih sebanyak 6\%-17\%.

Pneumonia dan penyakit paru obstruksi kronik adalah penyakit infeksi saluran pernapasan bawah akut yang banyak ditemukan. Pada penderita infeksi pneumonia dalam keadaan normal tidak terjadi pertumbuhan mikroorganisme di paru. Hal ini disebabkan karena adanya mekanisme pertahanan paru. Jika daya tahan tubuh tidak seimbang maka mikroorganisme dapat berkembang biak bahkan menimbulkan penyakit. Cara mikroorganisme mencapai saluran pernapasan ada beberapa tahap yaitu inokulasi langsung, penyebaran melalui pembuluh darah, inhalasi bahan aerosol, dan kolonisasi pada permukaan mukosa. Pada penderita PPOK organ yang diserang yaitu bronkus. Infeksi PPOK didahului dengan adanya infeksi pada bronkus atau paru dengan cara merusak dinding bronkus sehingga terjadi bronkiestasis. Pemeriksaan sputum pada penderita PPOK dapat ditandai dengan sputum berwarna kuning hingga hijau atau berbau busuk menandakan terjadinya infeksi sekunder pada bronkus sehingga pemeriksaan dilakukan secara mikrobiologis. Sputum berbau busuk menandakan infeksi sekunder yang disebabkan oleh bakteri anaerob seperti Klebsiella pneumoniae. Angka kejadian infeksi pneumoni yang disebabkan oleh Klebsiella pneumoniae sekitar 7\%-14\% sedangkan prevalensi kejadian PPOK didunia rata-rata berkisar 3-11\% (GOLD, 2015). Pada tahun 2013, di Amerika Serikat PPOK adalah penyebab utama kematian ketiga (America Lung Association, 2015). Prevalensi kejadian PPOK di Asia Pasifik rata-rata 6,3\% sedangkan di Indonesia menunjukkan prevalensi sebanyak 5,6\% (Regional COPD Working Group, 2003).

Tingginya persentase penderita infeksi saluran kemih, pneumoniae, dan PPOK yang disebabkan oleh $K$. pneumoniae memerlukan terapi dengan antibiotik. World Health Organization (WHO) menyatakan bahwa penatalaksana farmakologinya menggunakan antibiotik yang telah ditetapkan sebagai terapi empiris PPOK eksaserbasi akut yaitu amoksisilin, eritromisin, dan kloramfenikol (WHO, 2011 cit. Sonita and Masri, 2014). $K$. pneumoniae memiliki tingkat resistensi terhadap antibiotik ampisilin sebesar $76 \%$, sulfametoksazol dan trimetroprim sebesar $71 \%$, dan eritromisin sebesar $69 \%$. Penelitian tersebut juga menyatakan bahwa $K$. pneumoniae memiliki tingkat sensitivitas paling tinggi terhadap antibiotik netilmisin (53\%). K. pneumoniae juga bersifat sensitif terhadap antibiotik meropenem dan seftazidin. $K$. pneumoniae sensitif pada antibiotik-antibiotik tersebut, akan tetapi obat-obat tersebut baru dipasarkan sehingga penggunaan antibiotik ini tidak terlalu sering, jumlahnya terbatas, dan pertimbangan efek samping obat seperti nefrotoksik, ruam, diare, mual, dan muntah (Sonita dan Masri, 2014).

Berdasarkan hal tersebut perlu adanya alternatif lain atau terobosan baru dalam mengembangkan pengobatan bahan alam karena efektif dan lebih aman jika dibandingkan dengan obat sintesis. Bahan alam dari tumbuhan diharapkan menjadi solusi bagi masyarakat untuk dijadikan salah satu pengobatan alternatif untuk mengatasi penyakit yang ditimbulkan oleh $K$. pneumoniae. Tumbuhan yang ada di alam banyak ditemukan di sekitar lingkungan masyarakat sehingga mudah untuk diperoleh serta terjangkau dalam hal biaya.

Penelitian ini menggunakan sepuluh daun tanaman yang telah teruji memiliki aktivitas antibakteri yaitu daun kersen, daun salam, daun belimbing wuluh, daun sukun, daun kelengkeng, daun alpukat, daun binahong, daun kayu putih, daun rambutan, dan daun bambu. Sepuluh daun tanaman yang telah diteliti sebelumnya diekstraksi dengan pelarut etanol dan metanol. Ekstrak etanol daun kersen (Muntingia calabura L.) memiliki aktivitas antibakteri terhadap Escherichia coli (Buhian et al., 2016). 
Ekstrak etanol daun bambu mampu menghambat $K$. pneumonia (Wasnik and Tumane, 2014), ekstrak etanol daun rambutan (Nephelium lappaceum) dapat menghambat pertumbuhan E. coli (Nethaji et al., 2015) dan ekstrak etanol daun kelengkeng (Dimocarpus longan) dapat menghambat aktivitas Staphyllococcus aureus (Wisitsak et al., 2012).

Beberapa ekstrak yang disari menggunakan metanol juga telah diuji aktivitas antibakterinya. Ekstrak metanol daun sukun (Artocarpus altilis) (Ramanet al., 2012) dan ekstrak metanol daun salam (Eugenia polyantha) dapat menghambat pertumbuhan Pseudomonas aeruginosa (Gowri and Vasantha, 2014). Ekstrak metanol daun binahong (Anredera cordifolia) memiliki aktivitas terhadap bakteri $P$. aeruginosa dengan Konsentrasi Hambat Minimum sebesar $256 \mu \mathrm{g} / \mathrm{mL}$ (Nuryanti et al., 2014) sedangkan ekstrak metanol daun belimbing wuluh (Averrhoa bilimbi Linn) dengan konsentrasi $400 \mu \mathrm{g} /$ disk dapat menghambat aktivitas $P$. aeruginosa (Das et al., 2011). Ekstrak metanol daun alpukat (Persea americana) dengan konsentrasi 50 $\mathrm{mg} / \mathrm{mL}$ dapat menghambat pertumbuhan bakteri $K$. pneumoniae (Ogundare and Oladejo, 2014) dan ekstrak metanol daun kayu putih (Melaleuca leucadendra) memiliki aktivitas terhadap Staphylococcus aureus (Al-Abd et al., 2015). Penelitian ini dilakukan untuk mengetahui aktivitas antibakteri sepuluh ekstrak daun tanaman terhadap $K$. pneumoniae dan mengetahui golongan senyawa pada ekstrak daun yang memiliki aktivitas antibakteri tertinggi dan golongan senyawa aktif antibakterinya.

\section{METODOLOGI PENELITIAN}

Alat

Alat-alat yang akan digunakan dalam penelitian ini adalah alat-alat gelas (Pyrex®), mikropipet (Socorex), rotary evaporator (Heidolph), neraca analitik (Ohaus), waterbath (Memmert), inkubator bakteri (Memmert), oven (Memmert), autoklaf
(Hirayama), incubator shaker (New Brunswick Scientific), LAF (Laminar Air Flow) (CV. Srikandi Laboratory), vorteks (Thermolyne Corporation), dan mikroskop (Olympus).

\section{Bahan}

Bahan yang digunakan dalam penelitian ini antara lain sepuluh daun tanaman yaitu daun kersen, daun salam, daun belimbing wuluh, daun sukun, daun kelengkeng, daun alpukat, daun binahong, daun kayu putih, daun rambutan, dan daun bambu yang diperoleh dari daerah sekitar Kudus dan Bojonegoro, bakteri Klebsiella pneumoniae diperoleh dari Laboratorium Mikrobiologi, Fakultas Farmasi, Universitas Muhammadiyah Surakarta, etanol 70\%, media Mueller Hinton (MH), media BHI (Brain Heart Infusion), blank disk, larutan hidrogen peroksida $\left(\mathrm{H}_{2} \mathrm{O}_{2}\right), \mathrm{NaCl} 0,9 \%$, disk siprofloksasin, etanol 70\%, n-heksan, etil asetat, aseton, silika gel $\mathrm{GF}_{254}$, pereaksi semprot $\mathrm{FeCl}_{3}$, sitroborat, Dragendorff, dan vanillin-asam sulfat.

\section{Penyiapan Bahan}

Bahan penelitian yang sudah diperoleh yaitu daun kersen, daun salam, daun belimbing, daun sukun, daun kelengkeng, daun alpukat, daun binahong, daun kayu putih, daun rambutan, dan daun bambu dicuci dengan air mengalir hingga bersih untuk menghilangkan semua kotoran yang menempel pada daun-daun tersebut. Kemudian daun dikeringkan di bawah sinar matahari menggunakan penutup kain berwarna hitam. Hal tersebut dilakukan agar daun-daun tersebut terhindar dari degradasi metabolit sekunder akibat sinar matahari. Setelah itu daun yang sudah kering dihaluskan dengan blender untuk memperkecil ukuran.

\section{Ekstraksi}

Sebanyak lebih kurang 50 gram masingmasing serbuk daun direndam dalam 1500 $\mathrm{mL}$ etanol $70 \%$, kemudian dimaserasi selama 3x24 jam dan sesekali diaduk. Setelah itu maserat disaring menggunakan kertas saring. Lima ampas daun yaitu daun kersen, sukun, 
belimbing wuluh, kayu putih, dan bambu diremaserasi sedangkan lima ampas lainya yakni daun binahong, kelengkeng, alpukat, rambutan, dan salam hanya dimaserasi 1 kali. Kemudian filtrat dari masing-masing daun dipekatkan menggunakan evaporator. Hasil evaporasi kemudian diuapkan di atas waterbath hingga diperoleh ekstrak yang kental.

\section{Pembuatan Suspensi Bakteri}

Bakteri Klebsiella pneumoniae diambil sebanyak 3-5 koloni dengan ose bulat yang sudah steril dari persediaan stok bakteri, selanjutnya disuspensikan ke dalam $5 \mathrm{~mL}$ media cair BHI. Bakteri diinkubasi selama 26 jam dengan suhu $37^{\circ} \mathrm{C}$ di shaking incubator. Selanjutnya ditambahkan salin steril hingga kekeruhan sama dengan standar Mc.Farland $1,5 \times 10^{8} \mathrm{CFU} / \mathrm{mL}$.

\section{Pengujian Aktivitas Antibakteri}

Metode yang digunakan untuk uji aktivitas antibakteri adalah metode disk difusi agar. Suspensi bakteri diambil sebanyak 100 $\mu \mathrm{L}$ dimasukkan ke dalam tabung reaksi kosong kemudian ditambahkan salin steril hingga kekeruhan sama dengan standar McFarland 1,5 x $10^{8} \mathrm{CFU} / \mathrm{mL}$. Selanjutnya suspensi yang telah dihomogenkan dengan salin steril diambil $200 \mu \mathrm{L}$ kemudian ditetesi di atas media $\mathrm{MH}$ dan diratakan dengan spreader glass steril. Larutan ekstrak daun dengan konsentrasi $20 \% \mathrm{~b} / \mathrm{v}$ diambil $10 \mu \mathrm{L}$ selanjutnya diteteskan pada disk kosong lalu ditunggu sekitar 15 menit agar pelarut menguap. Disk kemudian diletakkan di media yang telah diinokulasi dengan bakteri Klebsiella pneumoniae. Kontrol positif menggunakan disk antibiotik siprofloksasin dan kontrol negatif menggunakan disk yang ditetesi etanol $70 \%$ sebanyak $10 \mu \mathrm{L}$. Kemudian kultur diinkubasi selama 24 jam dengan suhu $37^{\circ} \mathrm{C}$ dan diamati diameter zona hambat yang terbentuk.

\section{Kromatografi Lapis Tipis}

Plat KLT silika gel $\mathrm{GF}_{254}$ yang telah ditotolkan ekstrak daun sukun dan ekstrak daun kayu putih selanjutnya dimasukkan ke dalam bejana yang berisi fase gerak.
Pemisahan ekstrak etanol daun sukun menggunakan fase gerak n-heksan : etil asetat (6:4) sedangkan ekstrak etanol daun kayu putih menggunakan fase gerak n-heksan : aseton (6:1,5). Plat KLT hasil elusi diletakkan pada suhu ruang hingga kering. Kemudian plat diamati di bawah sinar tampak, UV $254 \mathrm{~nm}$, dan UV $366 \mathrm{~nm}$. Setiap plat KLT disemprot dengan reagen $\mathrm{FeCl}_{3}$ untuk mendeteksi adanya tanin dan polifenol, sitroborat untuk mengetahui adanya flavonoid, Dragendorff untuk mendeteksi adanya alkaloid, dan vanilin-asam sulfat untuk mendeteksi adanya terpenoid dan saponin.

\section{Bioautografi}

Metode bioautografi dilakukan untuk mengidentifikasi golongan senyawa aktif antibakteri. Suspensi bakteri Klebsiella pneumoniae yang telah dicampurkan dengan larutan salin diinokulasikan ke media $\mathrm{MH}$ sebanyak $200 \mu \mathrm{L}$, selanjutnya plat KLT yang telah dielusi ditempelkan pada media $\mathrm{MH}$, kemudian didiamkan selama 5 menit agar senyawa aktifnya dapat berdifusi ke dalam media. Setelah itu plat KLT diambil dari media, cawan Petri diinkubasi selama 24 jam dengan suhu $37^{\circ} \mathrm{C}$. Hasil inkubasi diamati, jika ada zona hambat dihitung nilai Rfnya. Senyawa aktif dalam ekstrak daun yang memiliki aktivitas antibakteri ditunjukkan dengan adanya daerah yang bening pada media MH. Nilai Rf hasil bioautografi dibandingkan dengan nilai $\mathrm{Rf}$ terdekat hasil KLT sehingga golongan senyawa yang memiliki aktivitas antibakteri dapat diketahui.

\section{Analisis Data}

Analisis hasil uji aktivitas antibakteri. Hasil skrining aktivitas antibakteri berupa diameter zona hambat yang terbentuk di sekitar disk. Hasil diameter semua zona hambat tersebut diukur dan dihitung rata-rata diameter dan SDnya (standar deviasi). Ekstrak daun tanaman yang memiliki aktivitas antibakteri terbesar ditentukan dari diameter zona hambat yang paling besar. 
Analisis hasil kromatografi lapis tipis. Ekstrak yang telah dielusi oleh fase gerak kemudian diamati pada sinar tampak, sinar UV 254, dan sinar UV 366 dan pengamatan setelah penyemprotan dengan reagen semprot. Reagen semprot yang digunakan adalah $\mathrm{FeCl} 3$, Dragendorff, sitroborat, dan vanillin-asam sulfat.Reagen $\mathrm{FeCl}_{3}$ untuk mendeteksi adanya tanin dan polifenol, sitroborat untuk mengetahui adanya flavonoid, Dragendorff untuk mendeteksi adanya alkaloid, dan vanilin-asam sulfat untuk mendeteksi adanya terpenoid dan saponin.

Analisis hasil bioautografi. Analisis uji bioautografi dilakukan dengan menghitung nilai $\mathrm{Rf}$ bercak yang menyebabkan hambatan pertumbuhan bakteri kemudian dicocokkan dengan nilai Rf hasil KLT. Pada tahap ini dapat diketahui golongan senyawa yang memiliki aktivitas antibakteri terhadap $K$. pneumoniae.

\section{HASIL DAN PEMBAHASAN}

Pada tahap ekstraksi didapatkan ekstrak kental pada masing-masing daun tanaman. Metode ekstraksi yang dipilih yakni maserasi karena cara pengerjaannya yang mudah dan alat- alat yang digunakan sederhana. Pelarut yang digunakan adalah etanol $70 \%$. Arifianti (2014) dalam Wijesekera (1991) menyatakan bahwa pelarut yang sering digunakan adalah alkohol karena merupakan pelarut pengekstraksi yang terbaik untuk hampir semua senyawa dengan bobot molekul rendah seperti saponin dan flavonoid. Hasil rendemen yang diperoleh berbeda-beda yakni berkisar antara 10,597\% sampai $24,485 \%$. Rendemen yang terendah diperoleh ekstrak daun salam sebesar 10,597\% sedangkan rendemen yang tertinggi diperoleh ekstrak daun kersen sebesar 24,485\% (Tabel 1).

Perbedaan perolehan nilai rendemen hasil ekstrak kental sepuluh daun tanaman dikarenakan perbedaan berat pada masingmasing simplisia. Hal ini juga diduga bahwa faktor penyebab rendemen ekstrak berbedabeda yang didapatkan saat proses maserasi ekstrak tanaman. Pada proses ekstraksi tersebut ada 5 serbuk daun yang dilakukan maserasi diantaranya daun binahong, daun kelengkeng, daun alpukat, daun rambutan, dan daun salam sedangkan 5 serbuk lain yaitu daun kersen, daun sukun, daun belimbing wuluh, daun bambu, dan daun kayu putih diremaserasi. Beberapa faktor yang mempengaruhi yaitu faktor kimia seperti jenis dan jumlah senyawa kimia, metode ekstraksi, dan pelarut yang digunakan (Depkes RI, 2000).

Skrining aktivitas antibakteri dilakukan untuk mengetahui aktivitas antibakteri ekstrak etanol $70 \%$ sepuluh daun terhadap $K$. pneumoniae. Metode yang digunakan yaitu metode difusi disk. Metode difusi disk metode yang sederhana yang dilakukan untuk

Tabel 1. Hasil ekstraksi sepuluh daun tanaman menggunakan etanol $70 \%$

\begin{tabular}{lccc}
\hline \multicolumn{1}{c}{ Sampel } & $\begin{array}{c}\text { Bobot } \\
\text { serbuk } \\
(\mathbf{g})\end{array}$ & $\begin{array}{c}\text { Bobot ekstrak } \\
(\mathbf{g})\end{array}$ & $\begin{array}{c}\text { Rendemen } \\
(\boldsymbol{\%})\end{array}$ \\
\hline Daun kayu putih & 50,59 & 9,76 & 19,292 \\
Daun salam & 55,20 & 5,85 & 10,597 \\
Daun bambu & 51,22 & 6,70 & 13,080 \\
Daun kelengkeng & 58,30 & 11,61 & 19,869 \\
Daun sukun & 32,92 & 3,87 & 11,755 \\
Daun kersen & 45,17 & 11,06 & 24,485 \\
Daun binahong & 49,50 & 5,70 & 11,515 \\
Daun rambutan & 55,30 & 8,57 & 15,497 \\
Daun alpukat & 60,80 & 7,90 & 12,993 \\
Daun belimbing wuluh & 53,46 & 9,19 & 17,190 \\
\hline
\end{tabular}


Tabel 2. Hasil uji aktivitas antibakteri ekstrak etanol $70 \%$ sepuluh daun tanaman terhadap Klebsiella pneumoniae

\begin{tabular}{lc}
\hline \multicolumn{1}{c}{ Sampel } & Rata-rata diameter zona hambat \pm SD (mm) \\
\hline Ekstrak daun kayu putih & $15,00 \pm 0$ \\
Ekstrak daun salam & $10,00 \pm 0$ \\
Ekstrak daun bambu & $6,00 \pm 0$ \\
Ekstrak daun kelengkeng & $11,67 \pm 1,52$ \\
Ekstrak daun sukun & $18,33 \pm 5,57$ \\
Ekstrak daun kersen & $10,83 \pm 0,76$ \\
Ekstrak daun binahong & $7,83 \pm 1,89$ \\
Ekstrak daun rambutan & $10,67 \pm 2,30$ \\
Ekstrak daun alpukat & $11,00 \pm 1,00$ \\
Ekstrak daun belimbing wuluh & $9,67 \pm 2,08$ \\
Etanol 70\% (K-) & $6,00 \pm 0$ \\
Siprofloksasin (K+) & $25,00 \pm 0$ \\
Keterangan: & \\
Diameter zona hambat termasuk diameter disk $(6 \mathrm{~mm})$ & \\
Hasil perhitungan merupakan hasil 3x uji
\end{tabular}

mengamati diameter zona hambat. Ada dua macam zona hambat yang terbentuk dalam metode difusi disk yakni zona hambat radikal dan zona hambat irradikal. Zona hambat radikal merupakan daerah di sekitar disk yang tidak ditumbuhi bakteri sedangkan zona hambat irradikal yakni daerah hambat di sekitar disk tetapi masih ada sedikit pertumbuhan bakteri (bakteri tidak terbunuh) (Bauer et al., 1966).

Uji aktivitas antibakteri menunjukkan bahwa dari sepuluh ekstrak etanol daun ada sembilan ekstrak yang memiliki aktivitas terhadap Klebsiella pneumoniae ditunjukkan dengan adanya zona hambat yang semuanya radikal. Hanya ekstrak etanol daun bambu yang tidak memiliki aktivitas antibakteri. Sembilan tanaman yang memiliki aktivitas antibakteri yaitu ekstrak etanol daun kayu putih dengan nilai rata-rata dan diameter zona hambat sebesar 15,00 $\pm 0 \mathrm{~mm}$, daun salam sebesar 10,00 $\pm 0 \mathrm{~mm}$; daun kelengkeng sebesar 11,67 $\pm 1,52 \mathrm{~mm}$; daun sukun sebesar $18,33 \pm 5,57 \mathrm{~mm}$; daun kersen sebesar 10,83 $\pm 0,76 \mathrm{~mm}$; daun binahong sebesar 7,83 \pm $1,89 \mathrm{~mm}$; daun rambutan sebesar 10,67 \pm 2,30 mm; daun alpukat sebesar 11,00 $\pm 1,00$ $\mathrm{mm}$; dan daun belimbing wuluh sebesar 9,67 $\pm 2,68 \mathrm{~mm}$ (Tabel 2). Ekstrak etanol daun sukun dan daun kayu putih memiliki diameter zona hambat yang besar.
Hasil uji aktivitas antibakteri menunjukkan bahwa ekstrak etanol daun sukun dan ekstrak etanol daun kayu putih mempunyai aktivitas antibakteri dengan nilai diameter zona hambat berturut-turut sebesar $18,33 \mathrm{~mm}$ dan $15,00 \mathrm{~mm}$. Raman et al. (2012) menyatakan bahwa ekstrak metanol daun sukun mempunyai aktivitas terhadap $K$. pneumoniae dengan diameter zona hambat sebesar 11,67 mm sedangkan pada penelitian Bharat and Praveen (2015) menyatakan bahwa ekstrak metanol daun kayu putih memiliki aktivitas antibakteri dengan diameter daerah hambat sebesar 17,00 mm. Perbedaan hasil tersebut kemungkinan disebabkan oleh penggunaan jenis pelarut. Metanol merupakan jenis pelarut yang mampu menarik lebih banyak jumlah senyawa metabolit sekunder dibandingkan dengan pelarut etanol (Suryanto dan Wehantouw, 2009). Mbaeyi dan Onwuka (2014) menyatakan senyawa aktif antibakteri yang terlibat dalam ekstrak daun sukun adalah saponin, tanin, alkaloid, dan flavonoid. Senyawa aktif pada ekstrak daun kayu putih yang diduga mempunyai aktivitas antibakteri adalah flavonoid dan fenolik (Al-Abd et al, 2015).

Berdasarkan hasil uji aktivitas antibakteri ektrak etanol $70 \%$ dapat disimpulkan bahwa ekstrak etanol daun kayu 
putih, sukun, kelengkeng, salam, kersen, binahong, rambutan, alpukat, dan belimbing wuluh mempunyai aktivitas antibakteri terhadap Klebsiella pneumoniae. Dua ekstrak memiliki diameter zona hambat terbesar yaitu ekstrak etanol daun sukun dan ekstrak etanol daun kayu putih. Oleh karena itu kedua ekstrak tersebut diteliti lebih lanjut pada uji KLT dan bioautografi yang bertujuan untuk mengetahui kandungan senyawa yang memiliki aktivitas antibakteri terhadap $K$. pneumoniae.

Uji Kromatografi Lapis Tipis (KLT) dilakukan untuk mengetahui kandungan senyawa dalam dua ekstrak yang memiliki diameter hambat besar yaitu ekstrak etanol daun sukun dan ekstrak etanol daun kayu putih. Fase gerak untuk uji KLT ekstrak etanol daun sukun adalah etil asetat:n-heksan (4:6) sedangkan fase gerak yang digunakan untuk ekstrak etanol daun kayu putih adalah aseton : n-heksan $(6: 1,5)$. Uji ini dilakukan untuk mengetahui golongan senyawa yang terkandung di dalam ekstrak etanol daun sukun dan daun kayu putih.

Hasil KLT dianalisis dengan melihat warna bercak yang terjadi setelah pemberian reagen semprot. Pereaksi semprot yang digunakan yaitu sitroborat, $\mathrm{FeCl}_{3}$, Dragendorff, dan vanillin-asam sulfat. Reagen sitroborat digunakan untuk mendeteksi senyawa flavonoid. Bercak menunjukkan hasil positif flavonoid jika setelah diberi pereaksi semprot sitroborat bercak berfluoresensi kuning hingga kehijauan (Markham, 1988) atau berwarna kuning-coklat dan oranye pada UV 366 (Nancy et al, 2015). Hasil yang diperoleh menunjukkan tidak adanya senyawa flavonoid dalam ekstrak etanol daun sukun sedangkan ekstrak etanol daun kayu putih positif mengandung flavonoid yang ditunjukkan dengan fluoresensi kehijauan pada Rf 0,42.

Pereaksi semprot $\mathrm{FeCl}_{3}$ digunakan untuk mendeteksi adanya senyawa tanin dan polifenol. Hasil positif ditunjukkan adanya bercak berwarna abu-abu dalam pengamatan visual (Saifudin, 2014) atau warna hijau hingga hitam (Ukoha et al, 2011). Hasil identifikasi KLT yang diperoleh menunjukkan hasil yang positif adanya senyawa tanin atau polifenol pada ekstrak etanol daun sukun ditandai dengan adanya bercak berwarna abu-abu dengan $\operatorname{Rf} 0,32$ sedangkan ekstrak etanol daun kayu putih terbukti senyawa tanin atau polifenol pada $\mathrm{Rf}$ 0,47 .

Pereaksi semprot Dragendorff digunakan untuk mendeteksi senyawa alkaloid. Hasil yang diperoleh menunjukkan bahwa ekstrak etanol daun sukun positif mengandung alkaloid ditandai dengan adanya bercak berwarna coklat di bawah sinar tampak pada Rf 0,47 sedangkan pada hasil KLT ekstrak etanol daun kayu putih tidak terdapat bercak berwarna coklat sehingga disimpulkan bahwa ekstrak tidak mengandung senyawa alkaloid. Vanillin-asam sulfat digunakan untuk mengidentifikasi adanya senyawa saponin dan terpenoid. Menurut Wagner and Bladt (1996) hasil positif saponin dan terpenoid ditandai dengan adanya bercak berwarna biru, biru hingga ungu pada pengamatan di bawah sinar tampak penyemprotan dengan vanilinasam sulfat. Hasil yang diperoleh menunjukkan bahwa kedua ekstrak yaitu ekstrak etanol daun sukun dan ekstrak etanol daun kayu putih memiliki kandungan senyawa saponin dan terpenoid. Ekstrak etanol daun sukun diduga mengandung senyawa saponin dan terpenoid dengan nilai Rf 0,57; Rf 0,67; Rf 0,77; dan 0,82 sedangkan senyawa saponin dan terpenoid pada ekstrak etanol daun kayu putih berada pada Rf 0,22; Rf 0,47; dan Rf 0,90.

Berdasarkan hasil yang diperoleh ekstrak etanol daun sukun mengandung golongan senyawa tanin, polifenol, alkaloid, terpenoid, dan saponin sedangkan kandungan senyawa pada ekstrak etanol daun kayu putih adalah 


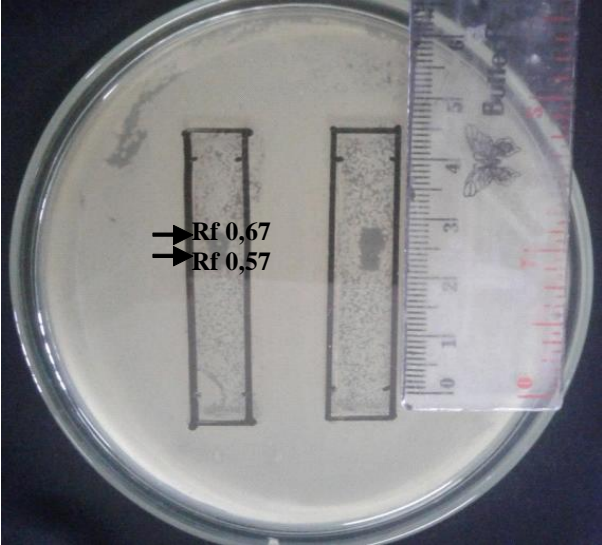

(A)

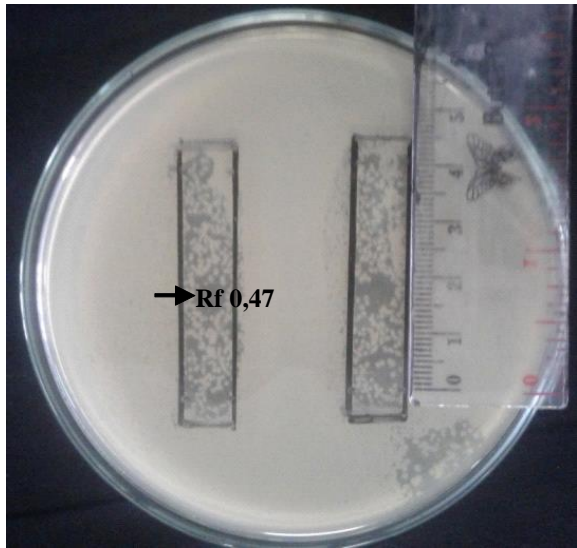

(B)

Gambar 1. Hasil bioautografi ekstrak etanol daun sukun (A), bioautografi ekstrak etanol daun kayu putih (B). Golongan senyawa dalam ekstrak daun sukun pada $\mathrm{Rf}$ 0,57 dan 0,67 adalah terpenoid dan saponin.

Golongan senyawa dalam ekstrak daun kayu putih pada $\mathrm{Rf}$ 0,47 adalah tanin, polifenol, terpenoid dan saponin.

senyawa tanin, polifenol, flavonoid, saponin, dan terpenoid.

Uji bioautografi bertujuan untuk mengetahui senyawa yang memiliki potensi dalam menghambat Klebsiella pneumoniae. Aktivitas antibakteri dapat dilihat dengan adanya zona hambat media $\mathrm{MH}$ yang telah ditanami bakteri. Uji ini dilakukan dengan menggunakan dua ekstrak yang memiliki diameter hambat terbesar yaitu ekstrak etanol daun sukun dan ekstrak etanol daun kayu putih. Hasil uji bioautografi menunjukkan adanya zona hambat pada daerah yang sebelumnya ditempeli plat KLT. Ekstrak etanol daun sukun memiliki aktivitas antibakteri ditandai dengan adanya zona hambat pada $\operatorname{Rf} 0,57$ dan $\operatorname{Rf} 0,67$ sedangkan pada ekstrak etanol daun kayu putih tidak ada pertumbuhan bakteri pada nilai Rf 0,47 (Gambar 1). Hasil uji KLT dan bioautografi menunjukkan bahwa golongan senyawa dalam ekstrak etanol daun sukun pada $\operatorname{Rf} 0,57$ dan Rf 0,67 adalah terpenoid dan saponin sedangkan golongan senyawa dalam ekstrak etanol daun kayu putih pada $\mathrm{Rf} 0,47$ adalah tanin, polifenol, terpenoid, dan saponin.

Mekanisme senyawa tanin sebagai antibakteri adalah dengan menghambat enzim reverse transcriptase dan topoisomerase
DNA sehingga sel bakteri tidak terbentuk (Nuria et al., 2009). Mekanisme polifenol sebagai antibakteri yaitu polifenol berperan sebagai toksin dalam protoplasma, juga dapat merusak, menembus dinding sel, dan mengendapkan protein sel bakteri sehingga dapat menyebabkan denaturasi protein, enzim menjadi tidak aktif, dan menyebabkan kebocoran sel (Heyne, 1987).

Mekanisme kerja saponin dalam antibakteri yaitu mengganggu permeabilitas membran sel bakteri, yang mengakibatkan kerusakan membran sel dan menyebabkan keluarnya berbagai komponen penting dari dalam sel bakteri yaitu protein, asam nukleat dan nukleotida (Ganiswarna, 1995). Senyawa terpenoid juga diketahui aktif melawan bakteri, tetapi mekanisme antibakterial triterpenoid masih belum benar-benar diketahui. Aktivitas antibakteri terpenoid diduga melibatkan pemecahan membran oleh komponen-komponen lipofilik (Cowan, 1999).

\section{KESIMPULAN}

Ekstrak etanol $70 \%$ daun kersen, rambutan, kelengkeng, sukun, salam, binahong, belimbing wuluh, alpukat, dan kayu putih mempunyai aktivitas antibakteri 
terhadap Klebsiella pneumoniae sedangkan ekstrak etanol daun bambu tidak memiliki aktivitas antibakteri. Senyawa yang terkandung dalam ekstrak etanol daun sukun yakni tanin, polifenol, alkaloid, saponin, dan terpenoid. Senyawa aktif yang diduga dapat menghambat aktivitas Klebsiella pneumoniae dalam ekstrak etanol daun sukun adalah saponin dan terpenoid.

\section{DAFTAR PUSTAKA}

Al-Abd N.M., Mohammed Nor Z., Mansor M., Azhar F., Hasan, M.S. and Kassim M., 2015, Antioxidant Antibacterial Activity and Phytochemical Characterization of Melaleuca cajuputi Extract, Journal of BMC Complementary and Alternative Medicine, 15 (1), 385.

America Lung Assosiation, 2015, Pneumonia, Terdapat di http://www.lung.org/lungdisease/influenza/in-depth resources/pneumonia-fact-sheet.html [Diakses pada 14 Oktober 2017]

Bauer A.W., Kirby W.M., Sherris J.C., Turck M., 1966, Antibiotic Susceptibility Testing By a Standardized Single Disk Method, Am J Clin Pathol, 45 (4), 493-6.

Buhian W.P.C., Rubio R.O., Valle D.L. and Puzon J.J.M., 2016, Bioactive Metabolite Profiles and Antimicrobial Activity of Ethanolic Extracts from Muntingia calabura L. Leaves and Stems, Article in Asian Pacific Journal of Tropical Biomedicine, 6 (8), 682-685.

Cowan M.M., 1999, Plant Products as Antimicrobial Agents, Clinical Microbiology Reviews, $12,564-582$.

Das S. C., Sultana S., Roy S. and Hasan, S.S., 2011, Antibacterial and cytotoxic activities of methanolic extracts of leaf and fruit parts of the plant Averrhoa Bilimbi (Oxalidaceae), American Journal of Scientific and Industrial Research, 531-536.

Elfidasari D., Noriko, Anita M., Feroza A., Fauziah S.C., 2014, Deteksi Bakteri Klebsiella pneumonia pada Beberapa Jenis Rokok Konsumsi Masyarakat, Jurnal Al-Azhar Indonesia Seri Sains dan Teknologi, 2 (1), 41-47.

Ganiswarna S., 1995, Farmakologi dan Terapi, Edisi 4, Penerbit UI, Jakarta.

Global Initiative for Chronic Obstruktive Lung Disease, 2015, Global Strategy for The Diagnosis, Managemant, and Prevention of Chronic Pulmonary Disease

Gowri S.S. and Vasantha K., 2010, Phytochemical Screening and Antibacterial Activity of Syzygium cumini L. (Myrtaceae) Leaves Extracts, International Journal of PharmTech Research, 2 (2), 1569-1573.

Heyne K., 1987, Tumbuhan Berguna Indonesia, Jilid III, Badan Litbang Kehutanan, Jakarta. 
Markham K.R., 1988, Cara Mengidentifikasi Flavonoid, diterjemahkan Kosasih Padmawinata, Penerbit ITB, Bandung.

Mbaeyi-Nwaoha I. E., and Onwuka C. P., 2014, Comparative Evaluation of Antimicrobial Properties and Pytochemical Composition of Artocarpus altilis Leaves Using Ethanol, n-Heksan, and Water, African Journal of Microbiology Research, 8 (37), 3409-3421.

Nansy E., Harwoko Pramono S., Nugroho A.E., 2015, Total flvonoid content and in vivo hypotensive effect of chloroform insolublefraction of Centella asiatica leaf extract, International Food Research Journal, 22 (5), 2119-2125.

Nethaji R., Thooyavan G., Nilla M. and Ashok K., 2015, Phytochemical Profiling, Antioxidant and Antimicrobial Activity of Methanol Extract In Rambutan Fruit (Nephelium Lappacium) Epicarp Against The Human Pathogens, International Journal of Current Innovation Research, 1 (9), 201-206.

Nuria M.C., Faizatun A. dan Sumantri, 2009, Uji Antibakteri Ekstrak Etanol Daun Jarak Pagar (Jatropha cuircas L.) terhadap Bakteri Staphylococcus aureus ATCC 25923, Escherichia coli ATCC 25922, dan Salmonella typhi ATCC 1408, Jurnal Ilmu ilmu Pertanian, 5, 26-37.

Nuryanti A., Yulinah E. and Firdianti I., 2014, Activity of Several Plant Extract Agains DrugSensitive and Drug-Resistant Microbes, International of Seminar on Natural Product Medicines, Procedia Chemistry, 13, 164-169.

Ogundare A. and Oladejo B., 2014, Antibacterial Activities of the Leaf and Bark Extract of Persea americana, American Journal of Ethnomedicine, 1 (1), 064-071.

Podschun R. and Ullman U., 1998, Klebsiella spp. as Nocosomial Pathogens, Epidemiology, Taxonomy, Typing Methods, and Pathogenicity Factors, Journal of American Society for Microbiology, 11, 589-603.

Raman V., Sudhahar D., Anandarajagopal K., 2012, Preliminary phytochemical investigation and screening of antimicrobial activity of leaf extracts of Artocarpus altilis, Asian Journal of Biological and Life Sciences, 1, 104-197.

Riskesdas, 2013, Riset Kesehatan Dasar, Badan Penelitian Kesehatan Kementrian Kesehatan RI Tahun 2013, Jakarta.

Saifudin A., 2014, Senyawa Alam Metabolit Sekunder (Teori Konsep dan Teknik Pemurnian), Deepublish, Yogyakarta.

Shaik G., Sujatha N. and Mehar S.K., 2014, Medicinal plants as Source of Antibacterial Agent to Counter Klebsiella pneumoniae, Journal of Applied Pharmaceutial Science, 4 (1), 135-147. 
Sonita A. and Masri M., 2014, Artikel Penelitian Pola Resistensi Bakteri pada Sputum Pasien PPOK Terhadap Beberapa Antibiotika di Laboraturium Mikrobiogi RSUP Dr. M. Djamil Periode 2010-2012, Jurnal Kesehatan Andalas, 3 (3), 354-357.

Ukoha P.O., Cemaluk E.A.C., Nnamdi O.L. and Madus E.P., 2011, Tannins and Other Phytochemical of the Samanaeasaman Pods and Their Antimicrobial Activities, African Journal of Pure and Applied Chemistry, 5 (8), 237-244.

Volk W.A. dan Wheeler M.F., 1993, Mikrobiologi Dasar, Erlangga, Jakarta.

Wagner H. and Bladt S., 1996, Plant Drugs Analysis: A Thin Layer Chromatography Atlas, 2nd ed., Germany, Springer.

Wasnik D.D. and Tumane P.M., 2014, Antibacterial Activity of Bambusa bambose L. against Multiple Drug Resistant (MDR) Bacteria Isolated from Clinical Specimen, International Journal of Pharmaceutical Sciences Review and Research, 25 (1), 215-218.

WHO, 2011, World Health Organization (WHO), Burden of COPD cit. Sonita A. and Masri M., 2014, Artikel Penelitian Pola Resistensi Bakteri pada Sputum Pasien PPOK Terhadap Beberapa Antibiotika di Laboraturium Mikrobiogi RSUP Dr. M. Djamil Periode 2010-2012, Jurnal Kesehatan Andalas, 3 (3), 354-357.

Wisitsak P., Nimkamnerd J., Thitipramote N., Saewan T., Chaiwut P. and Pintathong P., 2012, Comparison the Bioactive Compounds and Their Activities Between Longan And Litchi Seeds Extracts, Journal of $1^{\text {st }}$ Mae Fah Luang University International Conference. 